\title{
OS METADOLOMITOS DA REGIÃO DE MORRO AZUL-PR: CARACTERÍSTICAS GEOLÓGICAS DO MINÉRIO EXPLOTADO

\author{
SANDRA BOEIRA GUIMARÃES*
}

\author{
DISSERTAÇÃO DE MESTRADO - Programa de Pós-Graduação em Geologia - UFPR \\ DATA DE DEFESA: 3 mar. 2001
}

A região de Morro Azul é historicamente conhecida pela explotação de rochas metacalcárias, visando o fabrico da cal e produção de corretivo agrícola. Está localizada a noroeste da cidade de Almirante Tamandaré$\mathrm{PR}$, possuindo uma grande concentração de frentes de lavra. Mais de 30 empresas exploram hoje o metadolomito na região, mas essas empresas que atuam na área conhecem, no máximo, as suas frentes de lavra atuais. Isto faz com que hoje tenhamos no Paraná, embora de forma mecanizada, uma lavra de subsistência, pois o desconhecimento geológico dos materiais extraídos impossibilita a implantação de qualquer estratégia de aproveitamento, tanto do ponto de vista mercadológico quanto social. O presente estudo teve como objetivo caracterizar os critérios estratigráficos e petroquímicos dessas rochas para que, posteriormente, esses critérios fossem aplicados em outras regiões. A validação empírica foi a meta presente durante todo trabalho, pois o conhecimento dos mineradores é relevante para que se faça uma geologia aplicada. O principal litotipo carbonático aflorante na região é o metadolomito, metamorfisado em baixo grau, com idade deposicional Meso a Neoproterozóica. Essas rochas são representativas de uma seqüência plataformal carbonática, atribuídas às unidades litológicas Morro Grande e Rio Branco, da Formação Capirú, Grupo Açungui. O método de análise faciológica na interpretação de ambientes de sedimentação de unidades fanerozóicas foi aplicado em exposições dessas rochas. Para tal foram empregados critérios de observação, descrição, amostragem, levantamento de seções colunares, petrografia e análises químicas de rochas. As fácies foram individualizadas pela geometria, constituição litológica, texturas, estruturas sedimentares deposicionais e biogênicas e a interpretação integrada dessas análises. Os resultados evidenciaram um guia prospectivo de valor para a região. Níveis sotopostos às fácies resultantes de dissolução cárstica (grutas e cavernas) e ausência de estruturas estromatolíticas (esteiras algais) são os mais promissores para a exploração do bem mineral. A região estudada apresenta-se polideformada, sendo que as diversas fases de deformação podem ser relacionadas a três principais sistemas de deformação. Há heterogeneidade nesta deformação, pois se encontram faixas incipientemente deformadas, onde podem ser observadas abundantes estruturas sedimentares. Para a classificação da rocha e identificação dos teores de $\mathrm{CaO}$ e $\mathrm{MgO}$, foram utilizados os resultados de análises químicas e colorimetria de carbonatos em lâminas delgadas. Desta forma, a rocha explotada foi classificada como metadolomito, destacando como característica fundamental sua homogeneidade composicional em níveis distintos. A qualidade do metadolomito da região de Morro Azul e sua variação composicional não decorrem somente da faixa de metadolomito lavrada, mas também do nível estratigráfico explotado. Isto explica a seleção, por parte dos mineradores, de níveis preferenciais para exploração em detrimento de outros que acabam sendo abandonados e suas frentes de lavra desativadas. O principal resultado deste trabalho foi a identificação de um guia prospectivo onde, por meio deste, é possível caracterizar os níveis próprios para explotação. Na região de Morro Azul, a exemplo de todo estado do Paraná, a explotação do metadolomito ainda se restringe aos usos mais tradicionais, tais como a produção de cal e corretivo agrícola. Além destes usos, essa rocha é fonte de matéria-prima para diversas outras aplicações. $O$ desconhecimento das reservas, critérios de exploração e qualidades da matéria-prima são a causa contígua da deficiência de investimentos estratégicos no âmbito, cujo lance de crescimento tem sido refreado nos últimos anos. 